\title{
Biophotonic Combined Energy System (BCES)
}

\author{
U. Hellwig ${ }^{1}$, B. Kamm², F. Wildenauer ${ }^{1}$, A. Kölling ${ }^{3}$, S. Kieseler ${ }^{4}$ \\ ${ }^{1}$ University of Applied Science Wildau, Bahnhofstrasse 1, 15745 Wildau (Germany) \\ +00493375 508 170, +0049 3375508 586, udo.hellwig@th-wildau.de \\ ${ }^{2}$ BIOPOS Forschungsinstitut Bioaktive Polymersysteme e. V. \\ Kantstrasse 55, 14513 Teltow (Germany) \\ ${ }^{3}$ ERK Eckrohrkessel GmbH \\ Am Treptower Park 28 A - 12435 Berlin (Germany)
}

${ }^{4}$ Berlin University of Technology, Energy Processing and Conversion Technologies of Renewable Energies, Fasanenstrasse 89, 10963 Berlin (Germany)

\begin{abstract}
A comprehensive outline of a new approach in closed loop processing for energy utilisation and biomass generation using micro algae for electricity, heat and chemicals is presented - the Biophotonic Combined Energy System (BCES). The basic idea proposes that life-cycle management is an essential strategy in research and business. In terms of the BCES a carbon cycle driven by solar radiation via the photosystems of the Chlorophyceae species Scenedesmus rubescens serves as the core process from which valuable materials are extracted. The residues serve as the substrate for biogas generation which is used to run a Combined Heat and Power Plant (CHP) equipped with a gas motor and an exhaust gas carbon dioxide and heat recovery system. The electricity generated is fed into the public grid and the thermal energy is used to make the right temperature for the micro algae suspension. The carbon dioxide from biogas combustion is injected into the algae suspension thereby closing the elementary loop within the system.
\end{abstract}

\section{Key words}

Solar Energy Conversion, Micro Algae, Combined Heat and Power Plant (CHP), Bio-chemicals

\section{Algae Biomass}

At present algae and micro algae more and more become an important resource in research and technological development. Therefore, particularly regarding numerous applications for purposes of material use, one can differentiate between two branches of bio-refineries in general, the paths of generating solid, liquid and gaseous fuels for energy utilisation and the production of resources for material use [1]. The metabolites as well as the tissue matrix of microalgae are focussed strongly as an energy carrier, because the energetic yield of algae is significantly greater than that of lignocellulosic plants, due to the fact that the lower heating value is approximately $30 \%$ higher. In the context of raw materials there is distinguished

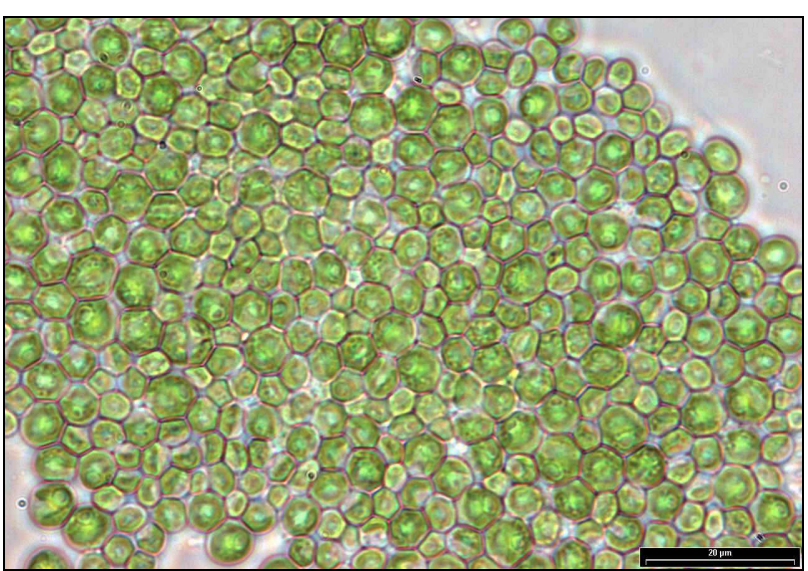

Fig. 1. Chlorophyceae species Scenedesmus rubescens culture.

between carbohydrates, lignins, lipids, proteins and special substances like dyes. The results of a brief literature study clearly showed that any kind of these raw materials can be extracted from micro algae, anyway $[2,3,4,5,6,7]$.

Table I. - Materials and Products from Micro Algae

\begin{tabular}{|l|l|l|}
\hline Species & Raw material & Final product \\
\hline \hline $\begin{array}{l}\text { Scenedesmus } \\
\text { rubescens }\end{array}$ & $\begin{array}{l}\text { lipids, } \\
\text { carotenoids }\end{array}$ & $\begin{array}{l}\text { fuels, aliments, } \\
\text { antioxidants }\end{array}$ \\
\hline $\begin{array}{l}\text { Chlamydomonas } \\
\text { spinosa }\end{array}$ & carbohydrates & fuels, plastics \\
\hline $\begin{array}{l}\text { Chlorella } \\
\text { stigmatophora }\end{array}$ & proteins & $\begin{array}{l}\text { nutriments, } \\
\text { foodstuffs }\end{array}$ \\
\hline $\begin{array}{l}\text { Calliarthron } \\
\text { cheilosporioides }\end{array}$ & lignins & fuels, chemicals \\
\hline $\begin{array}{l}\text { Chlamydomonas } \\
\text { reinhardtii }\end{array}$ & $\begin{array}{l}\text { hydrogen, } \\
\text { oxygen, proteins }\end{array}$ & $\begin{array}{l}\text { fuels, fine- } \\
\text { chemicals }\end{array}$ \\
\hline $\begin{array}{l}\text { Porphyridium } \\
\text { cruentum }\end{array}$ & $\begin{array}{l}\text { chlorophylls, } \\
\text { proteins }\end{array}$ & $\begin{array}{l}\text { pharmaceuticals, } \\
\text { dyes }\end{array}$ \\
\hline
\end{tabular}




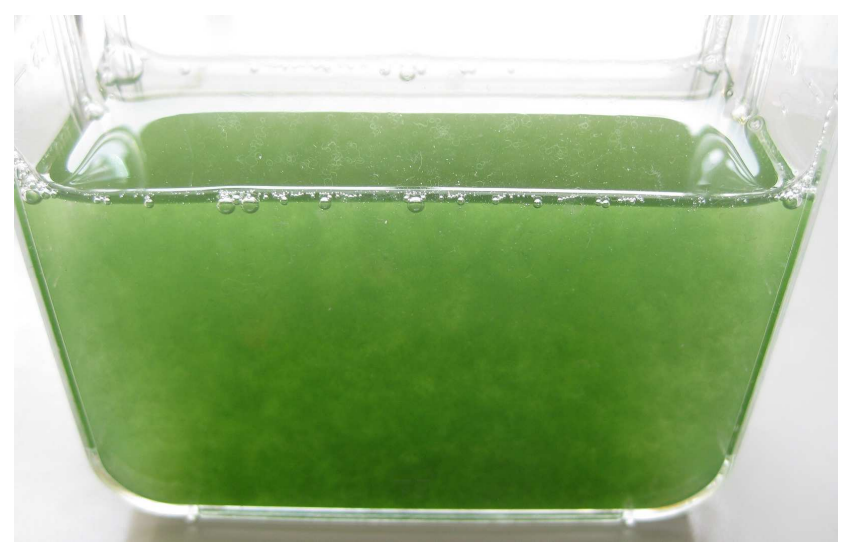

Fig. 2. Chlorophyceae species Scenedesmus rubescens strain.

Taking data about the lipid generation of Scenedesmus rubescens, for example, the content varies between 14 and 75 Mas. $-\%$, while the productivity of lipid is $0.1 \mathrm{~g} \cdot \mathrm{l}^{-1} \cdot \mathrm{d}^{-1}$ and of total biomass $0.5 \mathrm{~g} \cdot \mathrm{l}^{-1} \cdot \mathrm{d}^{-1}$, referred to the physiological state and the cultivation conditions. Fig. 2 shows a strain flask containing micro algae aquaculture.

\section{Conversion process chain}

Following these basic findings a technical concept including a reliable technology of a conversion process chain driven by solar radiation has been exposed. The dominating paradigms imply the importance of biofuels and fossile carbon dioxide sequestration. Besides these less notice is taken of the generation of chemicals, nutrients and animal feed, regenerative hydrogen and renewable bio coal. Principally the exclusive energetic use of algae biomass is scarcely an economically and environmentally sustainable business, definitely, because first costs must be lower than competetive prices of $5 €$-Ct. for bio coal and $1.50 €$ for bio fuel, whereas today these are amounting at least some $€ 40$ per kilogramme.

The particular species Scenedesmus rubescens has a remarkable potential to generate fatty acids resulting in an average lower heating value of about $25 \mathrm{MJ} / \mathrm{kg}$. Therefore it can be seen as equivalent of "green lignite", from which renewable fuels, chemicals and even biocoal can by synthesized, e. g. alkanes suitable for kerosene and renewable materials. On the other hand dyes and antioxidants like carotenes, astaxantenes and others have been detected, analysed and extracted. Table II shows an overview about some price margins achievable on the markets for metabolite products in general.

Beginning with comprehensive studies of the literature and patents the main purpose of the work was to utilise renewable energies and growing again raw materials using an alternative biomass potential without evoking conflicts with agriculture, nature conservancy and climate change precaution [8]. Two companies and three research facilities

Table II. - Economic assessment of valuable products

\begin{tabular}{|l|r|r|}
\hline \multicolumn{3}{|c|}{ SPECIFIC PRODUCT MARKET VALUE } \\
\hline Market Value & Min. Price & Max. Price \\
\hline Metabolite Group & \multicolumn{2}{|c|}{$€ \cdot \mathrm{kg}^{-1}$} \\
\hline Lipids & 10 & 150 \\
\hline Dyes & 500 & 10000 \\
\hline Amino Acids & 30 & 6000 \\
\hline
\end{tabular}

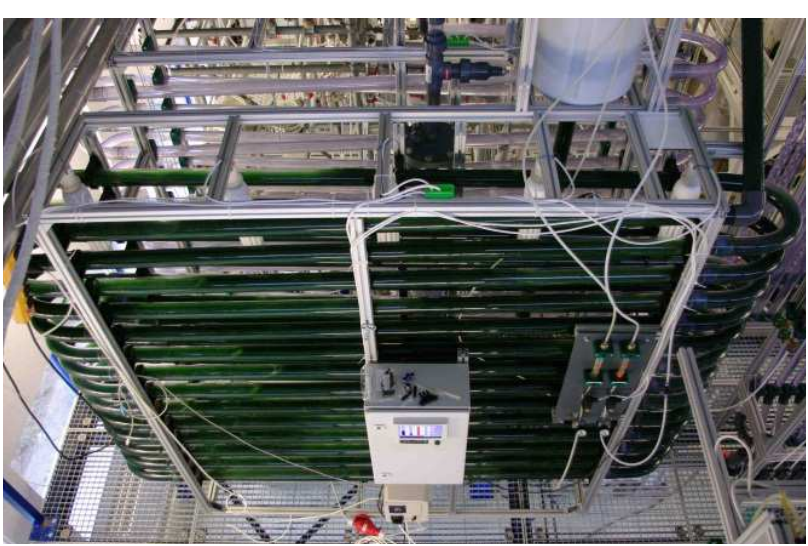

Fig. 3. Closed $2^{\circ}$ inclined-up-draft serpentine photobioreactor.

were involved in the work. From this point of view some requirement concerning the conception of systems technology have been deduced. To accomplish efficient processes of cultivation, harvesting and extraction with outstanding productivity it is of utmost importance to decrease the specific costs, emssions and resource consumptions. Regarding the material side a diversification of product lines on the basis of the precursors antioxidants, lipids, carbohydrates oder bio coal was carried out applying indicators of aggregated values added and marketability. The development of biochemical methods and processes to establish a fully extended algae based biorefinery in still in stages of early evolution at present. Finally the highest grades of recycling and reintegration of process energies and materials are necessary to gain economically exaptable returns on invest, operational costs and increased efficiency.

\section{Systems technology}

Referring to this basic scenarios and own technological resources regarding bio process, energy, production, material and chemical conversion techniques the main modules of the system were designed including varying photobioreactors, mixed radiation sources, algae biomass separation and refining, biogas generator, combined heat and power plant as well as process integration, measurement and controll units.

Basically a few particular micro algae species were selected, of which Scenedesmus rubescens became the standard organism, and useful cultivation procedures were acquired (Fig.2, Tab. III). From the results of experiments it became clear that this specie can be forced

Table III. - Nutrient medium

\begin{tabular}{|l|c|c|}
\hline \multicolumn{3}{|c|}{ NUTRIENT MEDIUM } \\
\hline \multicolumn{1}{|c|}{ Chemical } & Value & Unit \\
\hline $\mathrm{KNO}_{3}$ & 2.5 & $\mathrm{~g} \cdot \mathrm{l}^{-1}$ \\
\hline $\mathrm{MgSO}_{4}$ & 1.25 & $\mathrm{~g} \cdot \mathrm{l}^{-1}$ \\
\hline $\mathrm{KH}_{2} \mathrm{PO}_{4}$ & 0.625 & $\mathrm{~g} \cdot 1^{-1}$ \\
\hline $\mathrm{FeSO}_{4}$ & 0.005 & $\mathrm{~g} \cdot 1^{-1}$ \\
\hline $\mathrm{EDTA}^{-1}$ & 0.019 & $\mathrm{~g} \cdot \mathrm{l}^{-1}$ \\
\hline $\mathrm{H}_{3} \mathrm{BO}_{3}$ & 1.43 & $\mathrm{mg} \cdot 1^{-1}$ \\
\hline $\mathrm{MnCl}_{2} \cdot 4 \mathrm{H}_{2} \mathrm{O}$ & 0.905 & $\mathrm{mg} \cdot 1^{-1}$ \\
\hline $\mathrm{ZnSO}_{4} \cdot 7 \mathrm{H}_{2} \mathrm{O}$ & 0.111 & $\mathrm{mg} \cdot 1^{-1}$ \\
\hline $\mathrm{MoO}_{3}$ & 0.009 & $\mathrm{mg} \cdot 1^{-1}$ \\
\hline $\mathrm{NH}_{4} \mathrm{VO}_{3}$ & 0.0115 & $\mathrm{mg} \cdot 1^{-1}$ \\
\hline
\end{tabular}




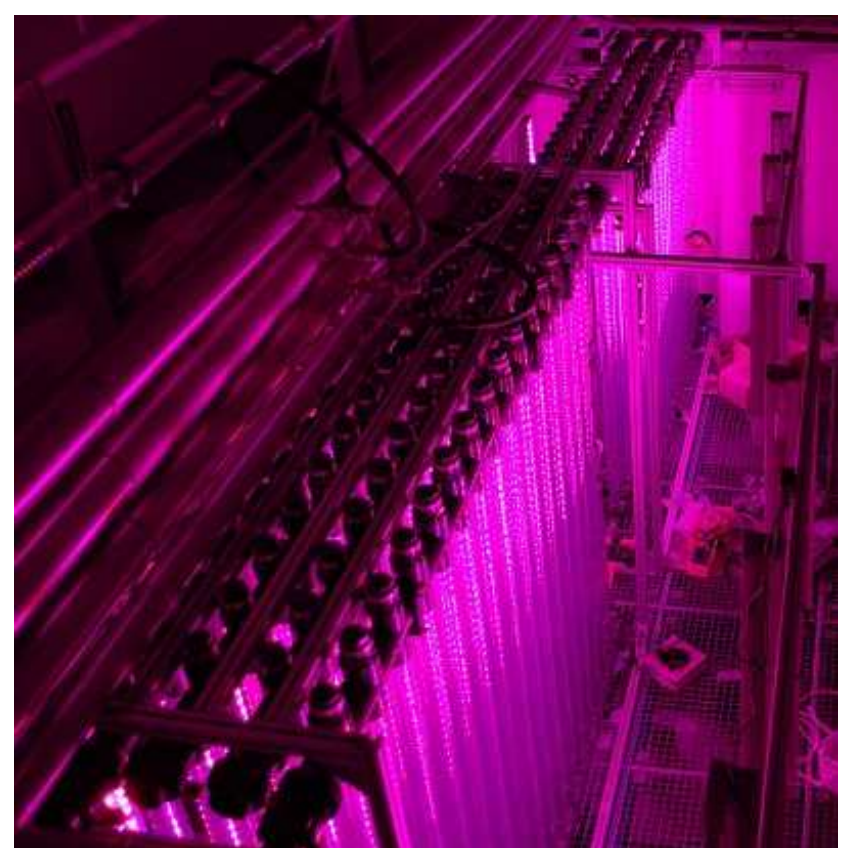

Fig. 4. Controlled multiple radiation of air-lift photobioreactors.

to grow both in a phototrophic and a heterotrophic state of cultivation, easily.

\section{A. Photobioreactor and Radiation Modules}

A couple of different photobioreactor modules were designed and engineered on the basis of innovative construction methods. Fig. 3 shows a closed $2^{\circ}$ inclined-updraft serpentine photobioreactor which in turn became the standard module with an effective volume of $0.22 \mathrm{~m}^{3}$, Fig. 4 and 5 the type of an air-lift photobioreactor. The design of the modules is tight-fitted to a profiled aluminium frame which has a vertical elevation of 2.2 or $3.4 \mathrm{~m}$, a horizontal width of $1.4 \mathrm{~m}$ and a depth of $0.5 \mathrm{~m}$. Inside the circulatory tube loops of the reactor the algae are supplied with light, nutrients and $\mathrm{CO}_{2}$, wherefore the $\mathrm{CO}_{2}$ maintenance is guaranteed by an integrated up-draft or air-lift system. The modules are carried out as a constitutive element in that way, that two or more modules can be connected to larger photobioreactor systems and the alignment of the piping system can be arranged vertically or horizontally for purposes of aggregation. If the modules are operated in a horizontal mode, the pumping is done with a flexible tube pump and the $\mathrm{CO}_{2}$ supply takes place in the receiver tank.
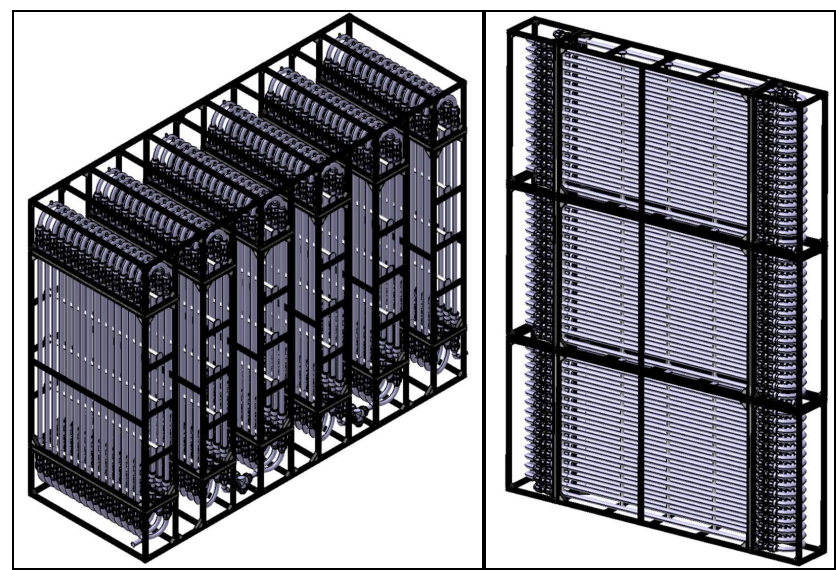

Fig. 5. Horizontal and vertical aggregation of air-lift reactors.

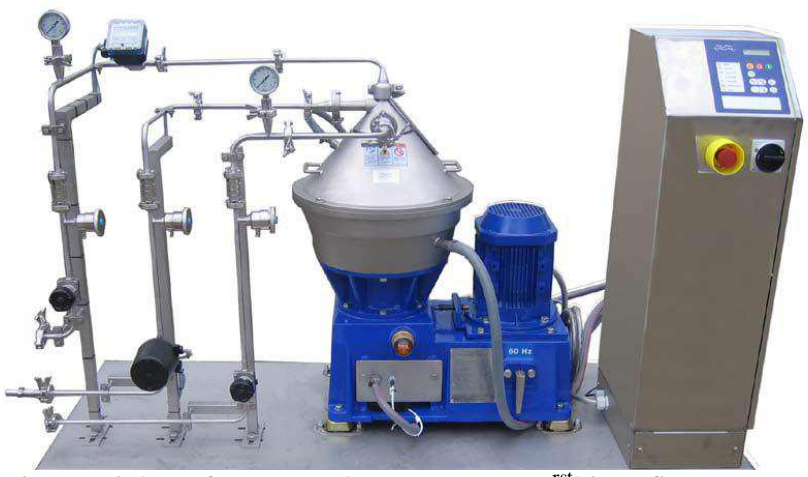

Fig. 6. High performance plate separator $-1^{\text {rtt }}$ bio-refinery stage.

With respect to tubing material the best transmitting and stable ones are fluorinated ethylpropylen (FEP) or even special laminated quartz glass of low ferrous oxide content, while polyvenylchloride (PVC) is good at wavelengths above $400 \mathrm{~nm}$ and mechanically tough, but less corrosion resistant. For puroses of low cost lightweight construction an innovative, thinwalled PVC material with improved high transmissivity and low costs was used. In some cases of high radiation intensity and ultraviolett rates the system should be installed in a greenhouse, which offers the opportunities to keep the environmental stress off and regulate the temperature in the photobioreactor at the physiological level of the micro algae.

For experimental reasons the radiation was applicated by mixed highly intensive light sources (Fig. 4). Broadband radiation was done with gas discharge lamps, and at wavelenths tuned to the photo systems of the particular micro algae blue and red diode plus spectral lamp sources were used. Solar radiation is of the type of black body including ultraviolett and infrared, the intensities amount $0.4 \mathrm{mmol}$ Photons per square meter in central Europe as well as under scattering conditions and $2.5 \mathrm{mmol} / \mathrm{m}^{2}$ in tropic regions being equivalent to a heat flow density of 100 to $290 \mathrm{~W} / \mathrm{m}^{2}$. About $45 \%$ of the radiation can be absorped by the photosystems, but the maximal effective rate is only one quarter of that, respectively.

\section{B. Algae Biomass Separation and Refining}

The average growth period of the micro algae both under phototrophic and heterotrophic conditions proved to be about 15 days. At that point the accumulated algae biomass reaches its maximum indicating that the output must be separated from the suspension (Tab. IV). Firstly

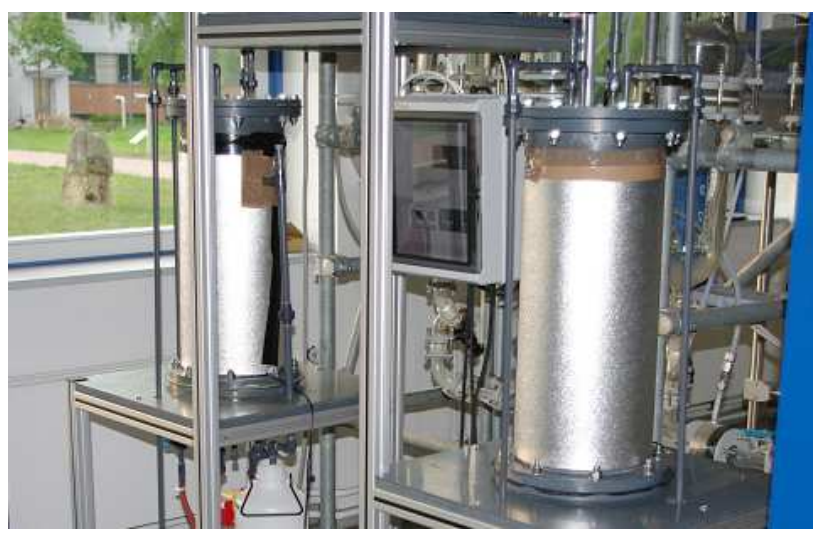

Fig. 7. Two-stage biogas reactor. 


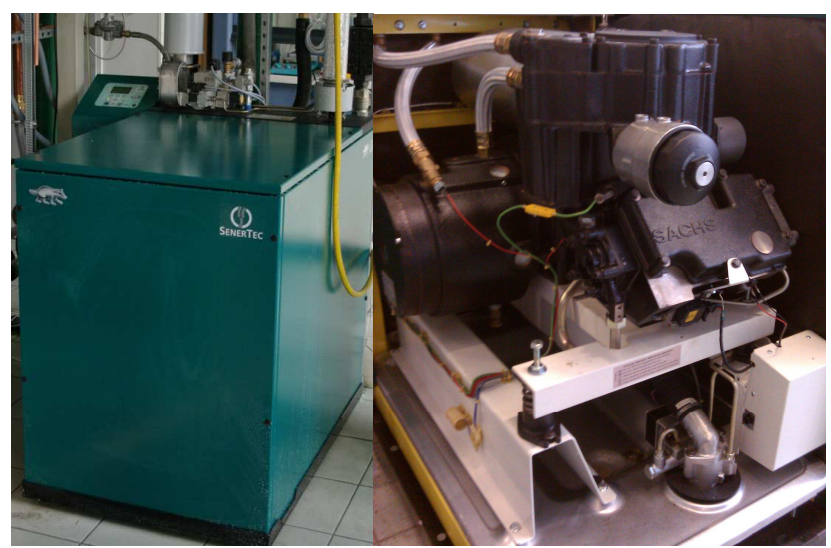

Fig. 8. Combined heat and power plant (CHP), Gas-Otto-Motor.

a mechanical separation is carried out, followed by a high performance centrifugal process by means of a plate separator (Fig. 6). According to requirements of analysis a water content below 0.05 Mas.-\% is achieved (Fig. 11).

Analysis are carried out using HPLC and diode array detector, photo absorption spectrometry and optical microscopy, as calibration standard serves a set of 37 fatty acid

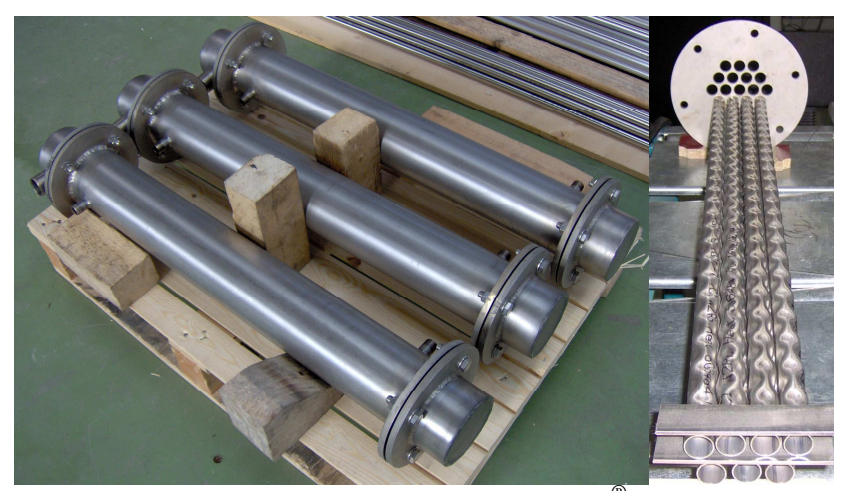

Fig. 9. Recuperative heat exchanger and ip tube ${ }^{\circledR}$-bundle.

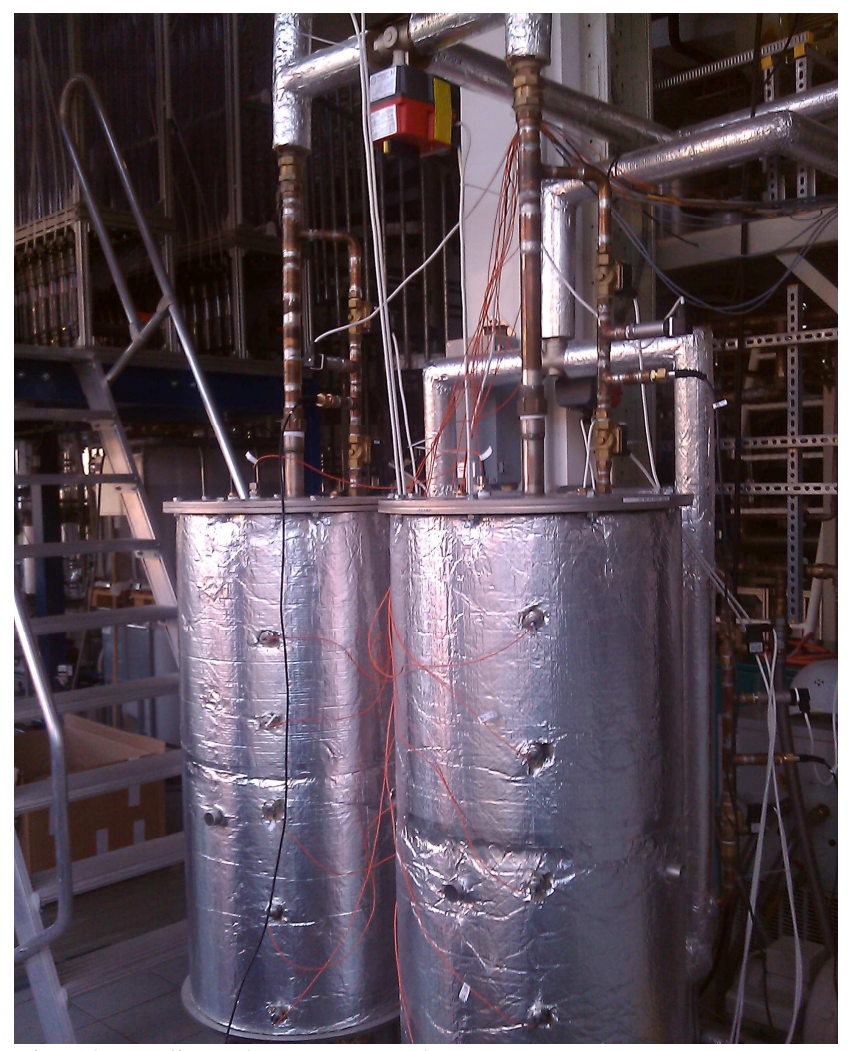

Fig. 10. Zeolite exhaust gas condenser.
Table IV. - Resulting Metabolite Quality

\begin{tabular}{|l|c|}
\hline \multicolumn{2}{|c|}{ MICRO ALGAE DRY MATTER COMPOSITION } \\
\hline Metabolite & Mas.-\% \\
\hline Amino Acids & 43 \\
\hline Lipids & 2.5 \\
\hline Carbohydrates & 4.3 \\
\hline Proteines & 42.13 \\
\hline Glycerol & 1.07 \\
\hline Minerals & 7.0 \\
\hline
\end{tabular}

methyl esters. The results in table IV seem to be a bit unusual, but one has to keep in mind, that the metabolisms of micro algae are a multiple function of the accessibility of nutrients and light as well as the environmental conditions. On the other hand one would expect a content of at least 1 Mas.-\% dyes, e. g. chlorophylls and carotenes, concomitantly. For example, according to literature the lipid content varies at least by a factor of five, depending on the availability of nitrous compounds [7].

Table V. - Biogas Quality

\begin{tabular}{|l|c|}
\hline \multicolumn{2}{|c|}{ GASEOUS COMPONENTS } \\
\hline Component & Vol.-\% \\
\hline Methane & 70.33 \\
\hline Carbon Dioxide & 20.71 \\
\hline Water vapour & 4.08 \\
\hline Nitrogen & 3.38 \\
\hline Oxygen & 1.43 \\
\hline Hydrogen sulphide & 0.07 \\
\hline
\end{tabular}

\section{Biogas Generation}

The residues from extraction serve as the substrate for the generation of biogas. In the first stage of the process macromolecular compounds are split into fragments which in turn are stripped down by fermentation and acidogenese under anaerobic conditions in small molecules. The thermo-sensitive biological degradation is effected by mesophilic bacteria at $37^{\circ} \mathrm{C}$ free from interferences, but not completely and perfectly, wherefore an additional stage is coupled down streams.

The quality of the biogas shown in Table $\mathrm{V}$ is remarkable, even when ballasts and spur gases are extracted, the gaseous fuel methane equals two thirds of the original volume and the lower heating value reaches $25.2 \mathrm{MJ} / \mathrm{m}^{3}$.

\section{Combined Heat and Power Plant}

According to the results of an evaluation in conformance with criteria of reliability, electric efficiency, invested and operational costs plus quality of service the process was engineered to become of the Gas-Otto-Type (Fig.8). At present one would have the options of solid oxide fuel

Table VI. - Exhaust Gas Quality

\begin{tabular}{|l|c|}
\hline \multicolumn{2}{|c|}{ GASEOUS COMPONENTS } \\
\hline Component & Vol.-\% \\
\hline Carbon Dioxide & 5.83 \\
\hline Water vapour & 3.53 \\
\hline Nitrogen & 81.54 \\
\hline Oxygen & 8.62 \\
\hline
\end{tabular}




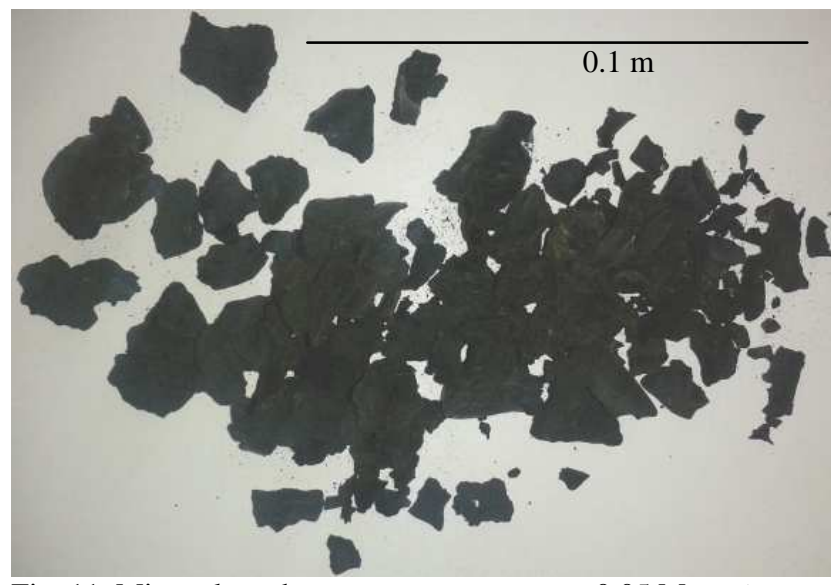

Fig. 11. Micro algae dry matter, water content 0.05 Mas.-\%.

cell or a novel radial expansion process according to the Tesla-Principle. The work machine for the combined heat and power generation with a thermal capacity of $20 \mathrm{~kW}$ is a 0.6 1-one-cylinder-motor with asynchronous generator and condensing boiler technology. It is run with the gas mentioned above having an electric efficiency of at least $27 \%$ and $72 \%$ thermal output.

The process integration is specified in a threefold way, the condensation of the water vapour in the exhaust gas, the recuperation of the latent heat of the exhaust gas and the induction of the carbon dioxide from exhaust gas into the algae suspension (Fig. 9,10, Tab. VI). The heat exchangers are equipped with innovative, highly effective tube bundles, the tubes are protected under the descriptor ip tube ${ }^{\circledR}$ industrial power tube. Nearly $20 \%$ of the latent heat can be recovered and used for the photobioreactor which is an excellent result. All in all $5 \%$ of the carbon dioxide is diluted in the algae suspension, a value substantial for most installation, but there is elbowroom for optimization.

\section{Conclusion}

A comprehensive outline of a new approach in closed loop processing for energy utilisation and biomass generation using micro algae for electricity, heat and chemicals is presented - the Biophotonic Combined Energy System (BCES). Full integration of BCES has been established on the energetic side as well as on the material side. Mass and

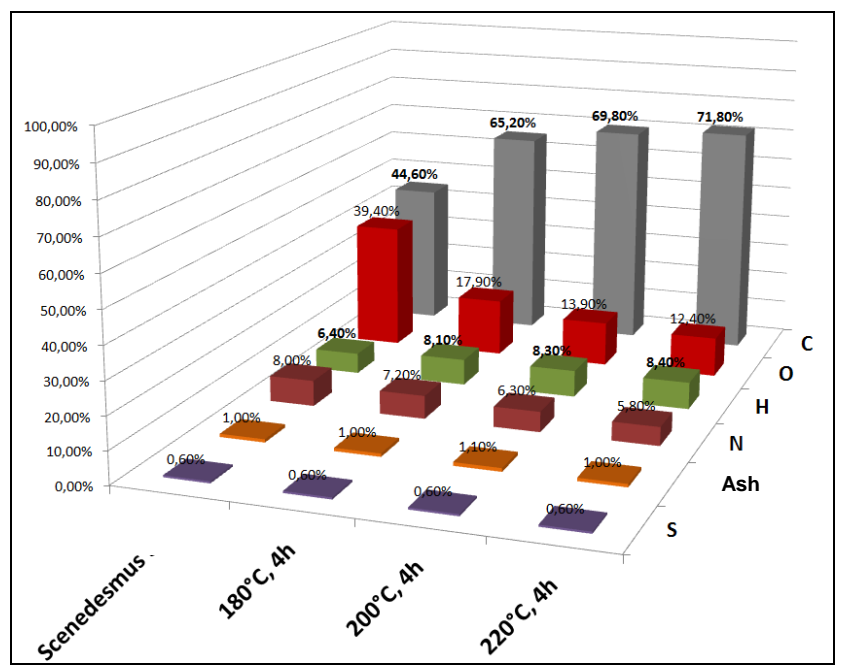

Fig. 12. Production of bio coal at different process conditions.

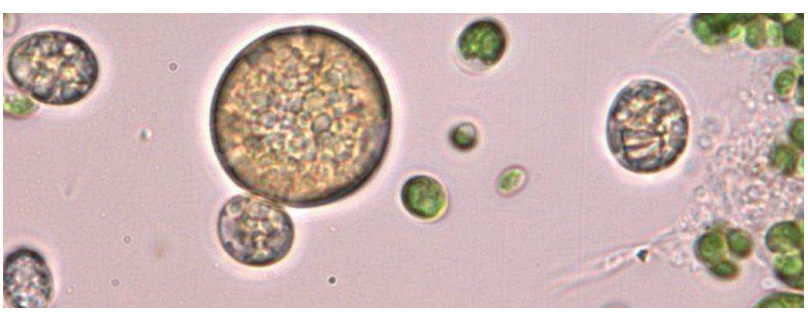

Fig. 13. Photophobic and heterotrophic state of micro algae.

energy flow balances were closed successfully, whereby the foundations of further differentiations and developments of the working cycles and the material flows have been laid, e g. the processing of a bio coal (Fig. 12).

At present the intensity of radiation is increased significantly up to $1.0 \mathrm{mmol}$ Photons per square meter at site. Consequently the intensity in situ at the surface of the algae in the suspension should be of the order of 0.2 to $0.25 \mathrm{mmol}$ Photons per square meter, indicating that the corresponding light saturation value is exceeded [9]. Therefore the species Scenedesmus rubescens changes its state from heterotrophic to become photophobic, whereby a dramatic transition in morphology takes place accompanied by an increase of the cells diametre one order of magnitude and supersaturation of lipids (Fig. 13).

We conclude that the system and its further development will significantly contribute to solving the most important tasks of the efficient use of renewable energies, material resources and climate change precaution.

\section{Acknowledgement}

The Federal Ministry of Economics and Technology for grants by the Central Innovation Programme SME.

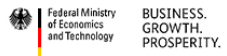

\section{References}

[1] B. Kamm, P. Gruber, M. Kamm, Biorefineries - Industrial Processes and Products. Wiley-VCH 2010.

[2] J. Fabregas, C. Herrero, Marine microalgae as a potential source of single cell protein (SCP), Applied Microbiology and Biotechnology 23 (1985) 2, pp. 110-113.

[3] P. Martone, J. Estevez, F. Lu, K. Ruel, C. Somerville, J. Ralph, Discovery of lignin in seaweed reveals convergent evolution of cell wall architecture. Current Biology 19(2) (2009) Jan 27, pp. 169-175.

[4] J. Mussgenug, O. Kruse, B. Hankamer et al., Engineering photosynthetic light capture: impacts on improved solar energy to biomass conversion. Plant Biotechnology Journal 5 (2007) 6, pp. 802-814.

[5] O. Pulz, W. Gross, Valuable products from biotechnology of microalgae. Applied Microbiology and Biotechnology 65 (2004) 6, pp. 635-648.

[6] J. Liu, J. Huang, F. Chen, Microalgae as feedstocks for Biodiesel Production, In: Biodiesel - Feedstocks and Processing, InTech, pp. 133-160.

[7] G. Huber, et al., Production of Liquid Alkanes by Aqueous-Phase Processing of Biomass-Derived Carbohydrates. Science 308 (2005) $3^{\text {rd }}$ June, pp. 1446-1450.

[8] G. Brooks et al., Food compositions of microalgal biomass. US Patent No. 0239712A1, $23^{\text {rd }}$ of September 2010.

[9] Y. Christi, Biodiesel from Microalgae, Biotechnology Advances 25 (2007) pp. 294-306. 